\title{
Global warming: preventing irreversibility
}

\author{
Aquecimento global: prevenindo a irreversibilidade
}

JAN-ERIK LANE*

RESUMO: A Convenção das Nações Unidas sobre Mudanças Climáticas se reúne novamente em Bonn, no outono, para a COP23 com Fiji como anfitrião. O foco deve estar no GOAL II no COP21: descarbonização com 30-40 por cento dos níveis de 2005 até 2030. Vários países agora cumprem a meta de suspender o aumento das emissões de CO2. E o resto deve ser solicitado e ajudado a fazê-lo. Mas o GOAL II é um desafio muito grande. Só pode ser realizado com investimentos maciços em parques de painéis solares.

PALAVRAS-CHAVE: Descarbonização e UNFCCC; a COP21.

ABSTRACT: The United Nations Framework Convention on Climate Change met again in Bonn for the COP23 in the fall with Fiji as host, the focus should have been upon the GOAL II in the COP21 Treaty: decarbonisation with 30-40 per cent of 2005 levels until 2030. Several countries now meet the GOAL I of halting the rise in CO2 emissions. And the rest should be asked and helped to do so. But the GOAL II is a very big challenge. It can only be fulfilled with massive investments in solar panel parks.

KEYWORDS: Decarbonisation and the UNFCCC; the COP21.

JEL Classification: Q4; Q5.

\section{INTRODUCTION}

What international governance in the United Nations Framework Convention on Climate Change - UNFCCC project aims at together with global state coordination is to engage in decarbonisation while securing economic development. The COP21 objectives are: GOAL I: Halt CO2 increases by 2018-2020; some countries already have done so, but far from all; GOAL II: Reduce CO2 emissions by 30-40 per cent, depending on how counts, by 2030 - an immense challenge; GOAL III: Complete decarbonisation by 2070-2075.

As world star physicist Stephen Hawkins recently remarked: global warming is close to becoming irreversible. The theory of global warming could not be more

\footnotetext{
* Emeritus professor at the University of Genova, Genova, Switzerland. E-mail: janeriklane34@gmail. com. Submitted: 10/July/2017; Approved: 26/February/2018.
} 
relevant for mankind, as irreversibility entails human extinction. French mathematician Joseph Fourier discovered global warming in the early $19^{\text {th }}$ century, but the theory was developed by Swedish chemist Arrhenius around 1895. He calculated that a doubling of $\mathrm{CO} 2 \mathrm{ppm}$ would be conducive to a 5 degree increase in global average temperature, which is not too far off the worst case ${ }^{12}$ scenario for the $21^{\text {rst }}$ century, according to UN expertise now.

Yet, it was not until Stephen Schneider published Global Warming in 1989 that the theory started to receive wide attention, no doubt strengthened by the work of Keeling in measuring CO2 ppm globally. Moreover, techniques for viewing the $\mathrm{CO} 2$ layer were developed, increasing the attention to climate change.

Now, the UN reacted with creating a few bodies to look into the changes going on, one of which was the COP framework. The economists jumped in besides the natural scientists, worried about the future costs of this transformation of the atmosphere. On the one hand, Kaya and associates presented in 1997 a model that explained CO2:s with energy and energy intensity of GDP. On the other hand, Stern called global warming the largest externality in human history, calling for international governance in order to stem the growth of greenhouse gases. Stern outlined in 2007 a number of activities aimed at reducing CO2 emissions, promising also a Super Fund to channel money from rich advanced nations to poor countries and developing economies. As little has been done through the UN system of meetings and agencies - transaction costs - up to date, Stern 2015 asked: "What are we waiting for?", neglecting his promise of the Super Fund (Ramesh, 2015).

\section{DANGERS FROM ANTHROPOGENIC CLIMATE CHANGE}

Considering the probable damages from global warming, it is astonishing that global warming theory has not been better recognized or even conceptually developed or empirically corroborated. There will be sooner or later:

Huge land losses along the costs;

Too high temperatures for men and women to work outside;

Food production decline;

Fish harvest decrease;

Droughts and starvation;

Lack of fresh water supply;

Drying up of rivers, affecting electricity supply;

Ocean acidification and species extinction;

Highly volatile climate with storms, rainfall and tornados with tremendous damages;

Deforestation and desertification;

Great damage to the poles and mountain glaciers. 
This list is far from complete or exhaustive. One could even mention worse outcomes, like the transformations of warm and cold currents in the oceans - Gulf Stream, North Atlantic Current for example. What one may underline is that so far no known negative feedback has been found that could stem global warming naturally. We seem to have mainly only positive feedbacks, meaning outcomes reinforce each other in the same direction. The situation in the Amazons and Borneo is basically "lost", and Siberian forests threatened.

\section{ENERGY-ENVIRONMENT CONUNDRUM}

Basically, roughly 90 per cent of all energy consumption comes from non-renewables. The COP21 call for decarbonisation involves a sharp reduction of fossil fuels up until 2030 in order to stabilize climate change with a 30-40 decrease in $\mathrm{CO} 2$ emissions. First, we see that $\mathrm{CO} 2$ emissions are closely connected with energy consumption, globally speaking. And the projections for energy augmentation in the $21^{\text {st }}$ century are enormous (EIA, BP, IEA).

Figure 1: Global GDP-CO2 link: $y=0,4092 x+25,03, R^{2}=0,987(N=26)$

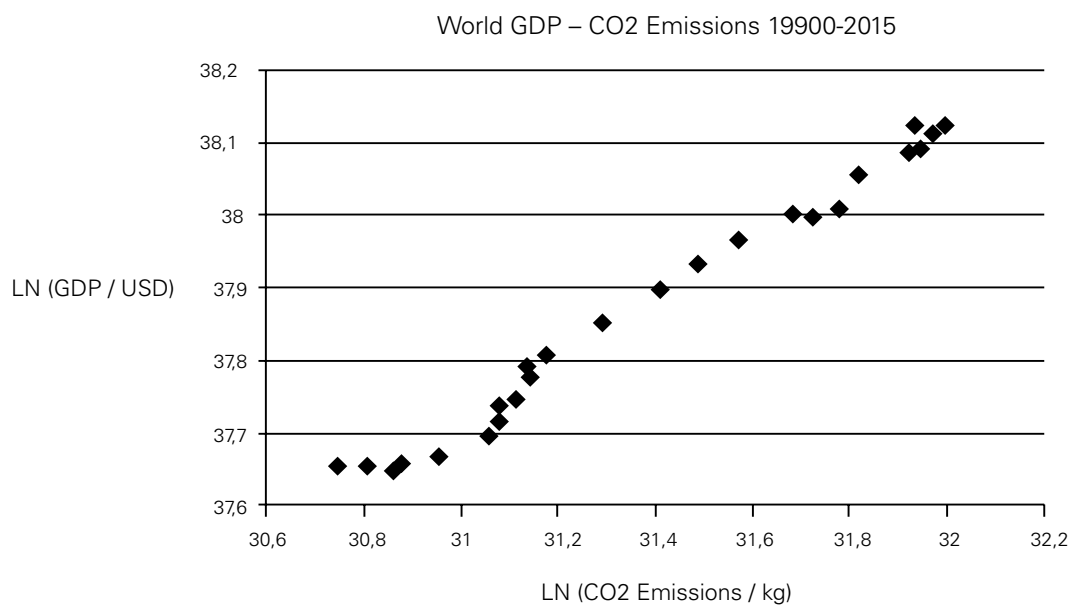

Source: BP Statistical Review of World Energy 2017, http://www.bp.com/statisticalreview; EDGAR. European Commission, Joint Research Centre (JRC)/PBL Netherlands Environmental Assessment Agency. Emission Database for Global Atmospheric Research (EDGAR), release version 4.3.2. http://edgar.jrc.ec.europe.eu, 2016 forthcoming. Janssens-Maenhout, G., Crippa, M., Guizzardi, D., Muntean, M., Schaaf, E., Olivier, J. G. J., Schure, K.M.: Fossil CO2 and GHG emissions of all world countries, EUR 28766 EN,Publications Office of the European Union, Luxembourg, 2017, ISBN 978-92-79-73207-2, doi:10.2760/709792, JRC107877. World Bank Data Indicators, http://data.worldbank.org: British Petroleum Statistical Review of World Energy 2016

The findings show that total GHG:s or CO2:s go with larger total GDP, i.e., GDP per person population. Decarbonisation is the policy promise to undo these 
inks by making GDP and energy consumption rely upon carbon neutral energy resources, like modern renewables and atomic energy. Thus, the upward sloping curves must be reversed but still slope outward. As, total energy consumed rises, so CO2:s increase. Secondly, energy means power and consequently affluence and wealth. It is hotly desired by men and women in today's world, as Figure 2 entails.

Figure 2: Energy consumption per capita globally

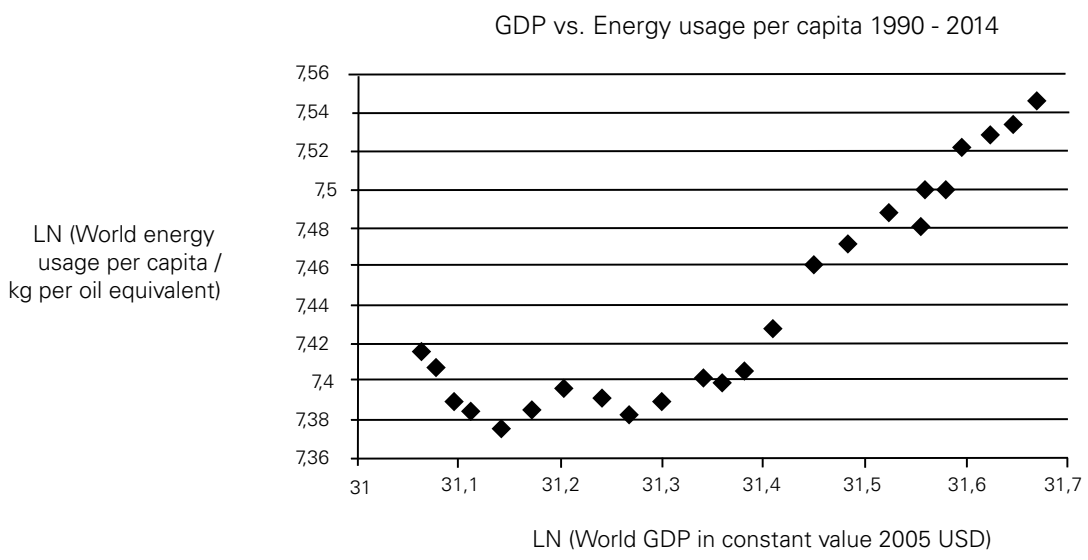

Source: World Bank national accounts data - data.worldbank.org; OECD National Accounts data files; World Resources Institute CAIT Climate Data Explorer - cait.wri.org; EU Joint Research Centre Emission Database for Global Atmospheric Research http://edgar.jrc.ec.europa.eu/overview.php:http://unfccc.int/ghg_data/ghg_ data_unfccc/time_series_annex_i/items/3814.php: International Energy Agency. Paris: Energy Information Administration. Washington, DC. British Petroleum Statistical Review of World Energy 2016

With such a demand for energy, resulting in sharply rising CO2:s per capita, how is mankind to avoid the horrendous consequences of climate change? One solution is the vast economic depression with strong cut backs in energy consumption, but no governments will deliberately choose this alternative, as it entails mass poverty and starvation deaths.

\section{THE COP21: IMPLEMENTATION OF GOAL II}

Let us first focus upon what this hoped for reduction of fossil fuels implies for the augmentation of renewable energy consumption, here solar power. The use of atomic power is highly contested, some countries closing reactors while others construct new and hopefully safer ones. I here bypass wind power and thermal power for the sake of simplicity in calculations.

Consider now Table 1, using the giant solar power station in Morocco as the benchmark - How many would be needed to replace the energy cut in fossil fuels and maintain the same energy amount, for a few selected countries with big $\mathrm{CO} 2$ emissions? 
Table 1: Number of Ouarzazate plants necessary in 2030 for COP21's GOAL II:

Global scene (Note: Average of 250 - 300 days of sunshine used for all entries except Australia, Indonesia, and Mexico, where 300 - 350 was used).

\begin{tabular}{|c|c|c|c|}
\hline Nation & $\begin{array}{l}\text { CO2 reduction pledge } \\
\% \text { of } 2005 \text { emissions }\end{array}$ & $\begin{array}{l}\text { Number of gigantic } \\
\text { solar plants needed } \\
\text { (Ouarzazate) }\end{array}$ & $\begin{array}{l}\text { Gigantic plants } \\
\text { needed for } 40 \% \\
\text { reduction }\end{array}$ \\
\hline United States & $26-28^{2}$ & 2.100 & 3.200 \\
\hline China & None $^{3}$ & 0 & 3.300 \\
\hline EU28 & $41-42$ & 2.300 & 2.300 \\
\hline India & None & 0 & 600 \\
\hline Japan & 26 & 460 & 700 \\
\hline Brazil & 43 & 180 & 170 \\
\hline Indonesia & 29 & 120 & 170 \\
\hline Canada & 30 & 230 & 300 \\
\hline Mexico & 25 & 120 & 200 \\
\hline Australia & $26-28$ & 130 & 190 \\
\hline Russia & None $^{4}$ & 0 & 940 \\
\hline World & $\mathrm{N} / \mathrm{A}$ & $\mathrm{N} / \mathrm{A}$ & 16.000 \\
\hline
\end{tabular}

Source: UN Framework Convention on Climate Change: CO2 Emission Reduction With Solar. http://www.solarmango.com/in/tools/solar-carbon-emission-reduction

Notes: 1) The United Sates has pulled out of the deal; 2) The United States of America made this pledge but has subsequently withdrawn from the agreement; 3) No absolute target; 4) Pledge is above current level, no reduction;

If countries rely to some extent upon wind or geo-thermal power or atomic power, the number in Table 1 will be reduced. The key question is: Can so much solar power be constructed in some 10 years? If not, Hawkins may be right. Thus, the COP23 should decide to embark upon an energy transformation of this colossal size.

Solar power investments will have to take many things into account: energy mix, climate, access to land, energy storage facilities, etc. They are preferable to nuclear power, which pushes the pollution problem into the distant future with other kinds of dangers. Wind power is accused to being detrimental to bird life, like in Israel's Golan Heights. Geo-thermal power comes from volcanic power and sites.

Let us look at the American scene in Table 2. 
Table 2: Number of Ouarzazate plants necessary in 2030 for COP21's GOAL II: American scene (Note: Average of $250-300$ days of sunshine per year was used for Canada, $300-350$ for the others).

\begin{tabular}{|l|c|c|c|}
\hline Nation & $\begin{array}{c}\text { CO2 reduction } \\
\text { pledge } / \\
\% \text { of } 2005 \text { emissions }\end{array}$ & $\begin{array}{c}\text { Number of gigantic } \\
\text { solar plants needed } \\
\text { (Ouarzazate) }\end{array}$ & $\begin{array}{c}\text { Gigantic plants } \\
\text { needed for 40\% } \\
\text { reduction }\end{array}$ \\
\hline Canada & 30 & 230 & 300 \\
\hline Mexico & 25 & 120 & 200 \\
\hline Argentina & None $^{3}$ & 0 & 80 \\
\hline Peru & None $^{3}$ & 0 & 15 \\
\hline Uruguay & None $^{3}$ & 0 & 3 \\
\hline Chile & 35 & 25 & 30 \\
\hline
\end{tabular}

Note: ${ }^{3}$ No absolute target.

It has been researched has much a climate of Canadian type impacts upon solar power efficiency. In any case, Canada will need backs ups for its many solar power parks, like gas power stations. Mexico has a very favourable situation for solar power, but will need financing from the Super Fund, promised in COP21 Treaty. In Latin America, solar power is the future, especially as water shortages may be expected. Chile can manage their quota, but Argentine needs the Super Fund for sure.

Table 3 has the data for the African scene with a few key countries, poor or medium income.

Table 3: Number of Ouarzazate plants necessary in 2030 for COP21's GOAL II:

African scene (Note: Average of $300-350$ days of sunshine per year was used).

\begin{tabular}{|l|c|c|c|}
\hline Nation & $\begin{array}{c}\text { CO2 reduction } \\
\text { pledge } / \\
\% \text { of } 2005 \text { emissions }\end{array}$ & $\begin{array}{c}\text { Number of gigantic } \\
\text { solar plants needed } \\
\text { (Ouarzazate) }\end{array}$ & $\begin{array}{c}\text { Gigantic plants } \\
\text { needed for 40 \% } \\
\text { reduction }\end{array}$ \\
\hline Algeria & $7-22^{5}$ & 8 & 50 \\
\hline Egypt & None ${ }^{3}$ & 0 & 80 \\
\hline Senegal & $5-21$ & 0,3 & 3 \\
\hline Ivory Coast & $28-36^{5}$ & 2 & 3 \\
\hline Ghana & $15-45^{5}$ & 1 & 3 \\
\hline Angola & $35-50^{5}$ & 6 & 4 \\
\hline Kenya & 30 & 3 & 2 \\
\hline Botswana & 17 & 1 & 1 \\
\hline Zambia & $25-47^{5}$ & 0,7 & 190 \\
\hline South Africa & None $^{3}$ & 0 & \\
\hline
\end{tabular}

Notes: ${ }^{3}$ No absolute target.; ${ }^{5}$ upper limit dependent on receiving financial support. 
Since Africa is poor, it does not use much energy like fossil fuels, except Maghreb as well as Egypt plus much polluting South Africa, which countries must make the energy transition as quickly as possible. The rest of Africa uses either wood coal, leading to deforestation, or water power. They can increase solar power without problems when helped financially.

Table 4 shows the number of huge solar parks necessary for a few Asian countries. The numbers are staggering, but can be fulfilled, if turned into the number ONE priority. Some of the poor nations need external financing and technical assistance.

Table 4: Number of Ouarzazate plants necessary in 2030 for COP21's GOAL II. Asian scene (Note: Average of 250 - 300 days of sunshine was used for Kazakhstan, $300-350$ days of sunshine per year for the others).

\begin{tabular}{|l|c|c|c|}
\hline Nation & \multicolumn{1}{|c|}{$\begin{array}{c}\text { CO2 reduction } \\
\text { pledge } / \\
\% \text { of } 2005 \text { emissions }\end{array}$} & $\begin{array}{c}\text { Number of gigantic } \\
\text { solar plants needed } \\
\text { (Ouarzazate) }\end{array}$ & $\begin{array}{c}\text { Gigantic plants } \\
\text { needed for 40\% } \\
\text { reduction }\end{array}$ \\
\hline Saudi Arabia & None ${ }^{3}$ & 0 & 150 \\
\hline Iran & $4-12^{5}$ & 22 & 220 \\
\hline Kazakhstan & None $^{3}$ & 0 & 100 \\
\hline Turkey & 21 & 60 & 120 \\
\hline Thailand & $20-25^{5}$ & 50 & 80 \\
\hline Malaysia & None $^{3}$ & 0 & 60 \\
\hline Pakistan & None $^{2}$ & 0 & 18 \\
\hline Bangladesh & 3,45 & 2 & \\
\hline
\end{tabular}

Notes: ${ }^{3}$ No absolute target; ${ }^{5}$ Upper limit dependent on receiving financial support.

Finally, we come to the European scene, where also great investments are needed, especially as nuclear power is reduced significantly and electrical cars will replace petrol ones, to a large extent.

Table 5: Number of Ouarzazate plants necessary in 2030 for COP21's GOAL II:

European scene (Note: Average of 250 - 300 days of sunshine per year was used)

\begin{tabular}{|l|c|c|c|}
\hline Nation & $\begin{array}{c}\text { CO2 reduction } \\
\text { pledge } / \\
\% \text { of 2005 emissions }\end{array}$ & $\begin{array}{c}\text { Number of gigantic } \\
\text { solar plants needed } \\
\text { (Ouarzazate) }\end{array}$ & $\begin{array}{c}\text { Gigantic plants } \\
\text { needed for 40\% } \\
\text { reduction }\end{array}$ \\
\hline Germany & $49^{6}$ & 550 & 450 \\
\hline France & $37^{6}$ & 210 & 220 \\
\hline Italy & $35^{6}$ & 230 & 270 \\
\hline Sweden & $42^{6}$ & 30 & 30 \\
\hline
\end{tabular}

Note: ${ }^{6} \mathrm{EU}$ joint pledge of $40 \%$ compared to 1990. 
Is there space to build all these solar parks, one may ask. But many small houses with solar roofs will also do well. Public buildings and company offices may be run on solar power from their roofs! Innovation is needed everywhere.

\section{CONCLUSION}

As the Keeling curve continues its relentless rise (Earth CO2), we must take Hawkins warning about irreversibility seriously. Moving now and up to 2030, according to the COP21's GOAL II for decarbonisation eliminates irreversibility. The solution is solar power parks of Ouarzazate type size. Above is a calculation of what is needed in many countries around the world, taking into account the insights of the research into GDP-energy-emission links. Time has come for halting and reducing $\mathrm{CO} 2$ emissions by real implementation and not utopian dreams of a sustainable economy (Sachs, 2015). There is nothing to wait for any longer (Stern, 2015), as the COP23 must set of the promised Super Fund. No time for politicking in the UN any longer (Conca, 2015; Vogler, 2016). A few days before the start of the UN global environment reunion COP23 (6-13 November 2017) in Bonn, the major study Climate Science Special Report: Fourth National Climate Assessment (USGCRP, 2017): was published in Washington. It examines the global warming problematic from the point of view of the US and the world, based upon years of research by a large group of US scholars. It renders an impressive list of climate change impacts upon the US territory and points decisively at human causes. We must then ask: Can really a set of global decarbonisation policies be implemented or managed? The most recent news about the severe negative impacts of global warming is an article in Science saying 1/4ths of the oceans have become oxygen empty - deoxygenation killing fishing and reducing local peoples' livelihood. Examining energy consumptions prediction, one observes that energy is expected to double by 2050 . There will be renewable energy for sure, but there is no global decarbonisation predicted by the stylized projections. Perhaps new energy demand will be satisfied by renewables, but the old carbonization structure of energy consumption will remain, so it seems?

\section{REFERENCES}

ARRHENIUS:"Arrhenius, Svante August" in Chambers's Encyclopædia. London: George Newnes, 1961, Vol. 1.

CONCA, K. (2015) An Unfinished Foundation. The United Nations and Global Environmental Governance. Oxford: OUP.

Climate Science Special Report: Fourth National Climate Assessment (USGCRP, 2017) https://assets. documentcloud.org/documents/4174364/Climate-Science-Special-Report-2017.pdf)

KAYA, Y., and YOKOBURI, K. (1997) Environment, energy, and economy: Strategies for sustainability. Tokyo: United Nations University Press. 
RAMESH, J. (2015) Green Signals: Ecology, Growth and Democracy in India. Oxford: Oxford University Press.

SACHS, J.D. (2015) The Age of Sustainable Development. New York: Columbia University Press.

SCHNEIDER, S.H.(1989) Global Warming: Are We Entering the Greenhouse Century?, Sierra Club Books; October 1989

STERN, N. (2007) The Economics of Climate Change. Oxford: Oxford University Press.

STERN, N. (2015) What are we waiting for? Cambridge: MA: MIT Press.

VOGLER, J. (2016) Climate Change in World Politics. Basingstoke: MacmillanPalgrave

\section{APPENDIX I}

The so-called Kaya model runs as follows:

(E1) Kaya's identity projects future carbon emissions on changes in Population (in billions), economic activity as GDP per capita (in thousands of \$US(1990) / person year), energy intensity in Watt years / dollar, and carbon intensity of energy as Gton C as $\mathrm{CO}_{2}$ per Tera Watt year.” (http://climatemodels.uchicago.edu/kaya/kaya.doc.html)

Concerning the equation (E1), it may seem premature to speak of a law or identity that explains carbon emissions completely, as if the Kaya identity were a deterministic natural law. It will not explain all the variation, as there is bound to be other factors that impact, at least to some extent. Thus, it is more proper to formulate it as a stochastic law-like proposition, where coefficients will be estimate using various data sets, without any assumption about stable universal parameters. Thus, we have this equation format for the Kaya probabilistic law-like proposition, as follows:

(E2) Multiple Regression: $Y=a+b_{1} X_{1}+b_{2} X_{2}+b_{3} X_{3}+\ldots+b_{t} X_{t}+u$

Note: $\mathrm{Y}=$ the variable that you are trying to predict (dependent variable); $\mathrm{X}=$ the variable that you are using to predict $\mathrm{Y}$ (independent variable); $\mathrm{a}=$ the intercept; $\mathrm{b}=$ the slope; $\mathrm{u}=$ the regression residual. Note: http://www.investopedia.com/terms/r/regression. asp\#ixzz4Mg4Eyugw

Thus, using the Kaya model for empirical research on global warming, the following anthropogenic conditions would affect positively carbon emissions:

(E3) CO2:s = F(GDP/capita, Population, Energy intensity, Carbon intensity).

I make an empirical estimation of this probabilistic Kaya model with a longitudinal test for 1990-2014, i.e., World data 1990 - 2015: (E4) Ln CO2 = 0,62*LN Population + $1,28 * \mathrm{LN}(\mathrm{GDP} /$ Capita $)+0,96 * \mathrm{LN}($ Energy/GDP) $; \mathrm{R} 2=.90$. 